\title{
Nutrient Use Efficiency and Productivity of Field Pea (Pisum sativum L.) Influenced by Combined Nitrogen and Sulphur Application
}

Waseem Raja, M. Anwar Bhat, B.A. Allie, Intikhab A. Jehangir, Ashaq Hussain, A.A. Saad, M. Salim Mir

10.18805/LR-4753

\begin{abstract}
Background: Field pea usually grows in the cold areas of the world unlike the other major pulses of the world. India is one of the largest producers of field pea (8.11 lakh tonnes) in the world on an area of 6.06 lakh hectares (FAOSTAT, 2019). The productivity of field pea is $13.37 \mathrm{q} / \mathrm{ha}$ which is quite low compared to France ( $40.4 \mathrm{q} / \mathrm{ha})$, Italy ( $30.99 \mathrm{q} / \mathrm{ha})$, Japan ( $24.8 \mathrm{q} / \mathrm{ha})$ and USA (23.8 q/ha) (FAOSTAT, 2019). One of the reason for low productivity of field pea in India besides other aspects is imbalanced use of fertilizers. However, to apply chemical fertilizers especially nitrogen causes environment pollution. Thus the present study was undertaken to investigate combined effect of sulphur and nitrogen on field pea to increase the productivity and to reduce nitrogen rate.

Methods: Field experiment were carried out at Faculty of Agriculture, Wadura, Sher-e-Kashmir University of Agricultural Sciences and Technology Kashmir, India during Rabi 2016-17 and 2017-18 under rainfed conditions. The experiment was laid out in factorial RBD with three levels of nitrogen $\left(N_{0}=0 \mathrm{~kg} / \mathrm{ha}, N_{1}=15 \mathrm{~kg} / \mathrm{ha}, N_{2}=30 \mathrm{~kg} / \mathrm{ha}\right)$ and four levels of sulphur $\left(\mathrm{S}_{0}=0 \mathrm{~kg} / \mathrm{ha}, \mathrm{S}_{1}=15 \mathrm{~kg} / \mathrm{ha}\right.$, $\mathrm{S}_{2}=30 \mathrm{~kg} / \mathrm{ha}, \mathrm{S}_{3}=45 \mathrm{~kg} / \mathrm{ha}$ ) with three replications. Field pea variety Shalimar Pea-1 was sown with row to row spacing of $30 \mathrm{~cm}$. During both the years, the crop was sown on $2^{\text {nd }}$ week of October and harvested at physiological maturity.

Result: Application $30 \mathrm{~kg} \mathrm{~S} / \mathrm{ha}$ and $15 \mathrm{~kg} \mathrm{~N} / \mathrm{ha}$ recorded significantly higher seed yield of field pea. Similarly the agronomic efficiency and yield attributing characters were also found significantly higher with application of $30 \mathrm{~kg} \mathrm{~S} / \mathrm{ha}$ and $15 \mathrm{~kg} \mathrm{~N} / \mathrm{ha}$. Further increasing levels of sulphur and nitrogen application do not significantly improved seed yield of field-pea. Similar trend was recorded in yield contributing character and agronomic efficiency.
\end{abstract}

Key words: Field pea, Interaction, Nitrogen, Sulphur.

\section{INTRODUCTION}

The demand for pulses in India will increase with a growing population as well as sustained economic growth (Raja et al. 2017). Field pea (Pisum sativum L.) is a major crop of grain legumes for human and animal feeding. The crop is a major protein source with high levels of high nutritional value amino acids, lysine and tryptophan (Bhat et al. 2013). Field pea is one of important rabi pulse crop grown in Kashmir valley. The adequate supply of macro and micro nutrients is necessary for plant growth and to get optimal yield. The $S$ and $\mathrm{N}$ plays vital part in the synthesis of proteins, thus these nutrients in plants are highly inter-related. Sulphur deficiency in crops has become widespread (Scherer, 2001) due to intensive cropping and use of sulphur free nitrogenous and phosphate fertilizer. Sulphur requirement is about $8 \mathrm{~kg}$ per tonne of legume seed. Fazili et al. (2008) stated that deficiency of $\mathrm{S}$ limits the efficiency of added $\mathrm{N}$, consequently, $S$ addition becomes essential to improve the efficiency of applied nitrogenous fertilizer. Nitrogen always results in low $\mathrm{N}$ use efficiency and serious $\mathrm{N}$ losses (Ma et al. 2010) and consequently leads to pollution of surface water, groundwater and the atmosphere (Liu et al. 2005). In order to increase the nitrogen use efficiency and to reduce the rate of nitrogen application the current investigation was undertaken to study of the response of field peas (Pisum sativum L.) to combined sulphur and nitrogen fertilization.
Division of Agronomy, Faculty of Agriculture, Wadura, Sher-iKashmir University of Agricultural Sciences and Technology Kashmir, Srinagar-190 025, Jammu and Kashmir, India.

Corresponding Author: Waseem Raja, Division of Agronomy, Faculty of Agriculture, Wadura, Sher-i-Kashmir University of Agricultural Sciences and Technology Kashmir, Srinagar-190 025, Jammu and Kashmir, India. Email: waseemra1@gmail.com

How to cite this article: Raja, W., Bhat, M.A., Allie, B.A., Jaheangir, I.A., Hussain, A., Saad, A.A. and Mir, M.S. (2022). Nutrient Use Efficiency and Productivity of Field Pea (Pisum sativum L.) Influenced by Combined Nitrogen and Sulphur Application. Legume Research. DOI: 10.18805/LR-4753.

Submitted: 29-07-2021 Accepted: 02-10-2021 Online: 26-02-2022

\section{MATERIALS AND METHODS}

The experiment was conducted at Agronomy farm of Shere-Kashmir University of Agricultural Sciences and Technology of Kashmir, Faculty of Agriculture, Wadura during rabi 2016-17 and 2017-18 under rainfed conditions. The experimental site falls in temperate zone of North Western Himalayas. The soil was sandy loam in texture having neutral $\mathrm{pH}$, organic carbon $1.82 \%, 208 \mathrm{~kg} / \mathrm{ha}$ of available nitrogen, $12.8 \mathrm{~kg} / \mathrm{ha}$ available $\mathrm{P}, 297 \mathrm{~kg}$ exchangeable $\mathrm{K}$ and $13.8 \mathrm{~kg}$ available $\mathrm{S}$ at the start of study. The experiment was laid out in factorial RBD with three levels 
of nitrogen $(0,15,30 \mathrm{~kg} / \mathrm{ha})$ and four levels of sulphur $(0$, $15,30,45 \mathrm{~kg} / \mathrm{ha}$ ) with three replications. Field pea variety Shalimar Pea-1 was sown with row to row spacing of 30 $\mathrm{cm}$. During both the years, the crop was sown on $2^{\text {nd }}$ week of October and harvested at physiological maturity. The urea and gypsum were the source used for nitrogen and sulphur respectively. Total quantity of nitrogen, phosphorous and potassium was applied as per the treatments just before sowing. Nodule count was done at start of flowering, for this reason 6 randomly selected plants from each plot were uprooted. The nutrient use efficiency was calculated as given by Dobermann (2007).

$$
\text { Agronomic efficiency }(A E)=(Y-Y 0) / F
$$

$\mathrm{Y}$ : Yield from fertilized plot $(\mathrm{Kg} / \mathrm{ha})$.

Y0: Yield from unfertilized plot $(\mathrm{Kg} / \mathrm{ha})$.

F : Quantity of fertilizer (N+S) applied (Kg/ha).

The equivalent energy values (Table 1 ) of various inputs and outputs as suggested by Saad et al. (2016) and Devasenapathy et al. (2009) were used for computing total energy input and energy output of field pea.

Output energy $(\mathrm{MJ} / \mathrm{ha})=$

Grain yield $(\mathrm{kg} / \mathrm{ha}) \times$ Energy coefficient of grain $(\mathrm{MJ} / \mathrm{kg}+$ straw yield $(\mathrm{kg} / \mathrm{ha}) \times$ Energy coefficient of straw $(\mathrm{MJ} / \mathrm{kg})$

$$
\text { Energy productivity }(\mathrm{kg} / \mathrm{MJ})=\frac{\text { Crop yield }(\mathrm{kg} / \mathrm{ha})}{\text { Input energy }(\mathrm{MJ} / \mathrm{ha})}
$$

Table 1: Energy coefficients used in the study.

\begin{tabular}{lcc}
\hline Particulars & Units & Equivalent energy (MJ) \\
\hline Inputs & & \\
Human labour Adult man & Man-hour & 1.96 \\
Diesel & Litre & 56.31 \\
Farm machinery & $\mathrm{kg}$ & 62.70 \\
(Disc harrow, Cultivator) & & \\
Chemical fertilizers & & \\
$\mathrm{N}$ & $\mathrm{kg}$ & 60.60 \\
$\mathrm{P}_{2} \mathrm{O}_{5}$ & $\mathrm{~kg}$ & 11.10 \\
$\mathrm{~K}_{2} \mathrm{O}$ & $\mathrm{kg}$ & 6.70 \\
Gypsum & $\mathrm{kg}$ & 10.0 \\
Outputs & & \\
Grain (field pea) & $\mathrm{kg}$ & 14.7 \\
Straw (field pea) & $\mathrm{kg}$ & 12.5 \\
\hline
\end{tabular}

\section{RESULTS AND DISCUSSION}

\section{Number of root nodules per plant}

The data in Table 2 revealed that number of nodules per plant showed positive relationship with increased sulphur levels and negative relationship with increased nitrogen levels. However the significantly higher nodule count per plant was recorded with application of $30 \mathrm{~kg} \mathrm{~S} / \mathrm{ha}$ without nitrogen. Further increase in sulphur had not significantly increased number of nodule per plant. Higher number nodules per at higher levels of sulphur were also reported by Chandra D. and Khaldelwal (2009) in chickpea and Munshi et al. (2001) in groundnut.

\section{Yield contributing characters}

During 2016, the application of $30 \mathrm{~kg} \mathrm{~N} /$ ha have recorded significantly higher yield attributing characters (number of seeds per plant and 100 seed weight) of field pea than no application of nitrogen, however was statistically at par to $15 \mathrm{~kg} \mathrm{~N} / \mathrm{ha}$ application (Table 3). Similar trend was observed during 2017. Higher yield contributing characters observed at $30 \mathrm{~kg} \mathrm{~N} /$ ha could be due to greater partitioning of dry matter into the economic portion i.e., to seed and favourable growth nutrient uptake. This was evident by the consistent results exhibited by application of nitrogen in both the seasons. Low pod yield recorded under control plots during the study could be due to insufficient essential element (nitrogen) at early growth stages. Nannim et al. (2018) also found higher seed yield of field pea with the higher application of nitrogen. Similar results were also reported by Sinclair (2004).

Sulphur application also registered significantly higher yield contributing characters of field pea upto to $30 \mathrm{~kg} \mathrm{~S} / \mathrm{ha}$ (Table 3). However further increase in sulphur level (45 kg/ha) had not significantly increased yield contributing characters. Similarly the levels of sulphur up to $40 \mathrm{~kg} / \mathrm{ha}$ showed linear increase the growth, yield attributes, seed and stalk yield of chickpea (Nawange et al. 2011).

\section{Seed yield}

The seed yield increased with increase in sulphur and nitrogen levels during both year of study (Table 4). However significantly higher seed yield was recorded with application of $30 \mathrm{~kg} \mathrm{~S} / \mathrm{ha}$ and $15 \mathrm{~kg} \mathrm{~N} / \mathrm{ha}$. Further increases in sulphur and nitrogen levels had not registered significant increase

\begin{tabular}{|c|c|c|c|c|c|c|}
\hline \multirow{3}{*}{ Treatments } & \multicolumn{6}{|c|}{ Nodules/plant } \\
\hline & \multicolumn{3}{|c|}{$2016-17$} & \multicolumn{3}{|c|}{$2017-18$} \\
\hline & $\mathrm{N}_{0}$ & $\mathrm{~N}_{1}$ & $\mathrm{~N}_{2}$ & $\mathrm{~N}_{0}$ & $\mathrm{~N}_{1}$ & $\mathrm{~N}_{2}$ \\
\hline $\mathrm{S}_{0}$ & 21.4 & 20.1 & 19.6 & 22.3 & 21.4 & 20.2 \\
\hline $\mathrm{S}_{1}$ & 25.1 & 23.5 & 22.2 & 24.8 & 23.9 & 23.7 \\
\hline $\mathrm{S}_{2}$ & 32.6 & 30.7 & 29.8 & 33.4 & 32.1 & 30.4 \\
\hline \multirow[t]{2}{*}{$\mathrm{S}_{3}$} & 33.7 & 31.9 & 30.5 & 33.9 & 32.8 & 31.7 \\
\hline & & C.D & S.Em \pm & & C.D & S.Em \pm \\
\hline Sulphur $\times$ Nitrogen & & 3.05 & 0.94 & & 3.17 & 1.03 \\
\hline
\end{tabular}

Table 2: Interaction effect of different levels of sulphur and nitrogen on number of nodule per plant of field pea. 
Nutrient Use Efficiency and Productivity of Field Pea (Pisum sativum L.) Influenced by Combined Nitrogen and Sulphur Application

in seed yield of field pea. This may be attributed to higher number of nodules/ plant, seed/plant and 100 seed weight with higher levels of sulphur application and higher number of yield contributing characters with higher levels of nitrogen. Similar results were also reported by Nawange et al. (2011) in chickpea, Jamal et al. $(2005 ; 2006)$ in soybean and Rao et al. (2001).

\section{Nutrient use efficiency}

The nutrient use efficiency was significantly influenced with application of varied rates of nitrogen and sulphur fertilizer. The response ( $\mathrm{kg}$ grain increase/kg nutrient applied) of field pea was maximum (21.53 and 20.69) with combined nitrogen $(15 \mathrm{~kg} / \mathrm{ha})$ and sulphur $(30 \mathrm{~kg} / \mathrm{ha})$ application in both years

Table 3: Influence of different levels of sulphur and nitrogen fertilization on yield contributing characters.

\begin{tabular}{lcccc}
\hline \multirow{2}{*}{ Treatments } & \multicolumn{2}{c}{ Seeds/plant } & \multicolumn{2}{c}{ 100 seed weight $(\mathrm{g})$} \\
\cline { 2 - 5 } & $2016-17$ & $2017-18$ & $2016-17$ & $2017-18$ \\
\hline $\mathrm{N}_{0}$ & 32.6 & 36.8 & 18.37 & 19.13 \\
$\mathrm{~N}_{1}$ & 48.5 & 56.2 & 21.62 & 22.72 \\
$\mathrm{~N}_{2}$ & 50.1 & 61.5 & 22.98 & 24.15 \\
$\mathrm{~S} . \mathrm{Em} \pm$ & 1.67 & 2.04 & 0.302 & 0.416 \\
$\mathrm{C} . \mathrm{D} .(\mathrm{P}=0.05)$ & 5.37 & 6.63 & 0.938 & 1.362 \\
$\mathrm{~S}_{0}$ & 34.03 & 42.6 & 19.16 & 19.83 \\
$\mathrm{~S}_{1}$ & 41.21 & 58.7 & 20.51 & 21.62 \\
$\mathrm{~S}_{2}$ & 48.97 & 71.9 & 21.69 & 23.57 \\
$\mathrm{~S}_{3}$ & 49.72 & 74.5 & 21.97 & 23.96 \\
$\mathrm{~S} . \mathrm{Em} \pm$ & 2.20 & 3.83 & 0.37 & 0.461 \\
C.D.(0.05) & 6.27 & 10.47 & 1.12 & 1.531 \\
\hline
\end{tabular}

compared to other treatments (Table 5). Similar findings were also reported by Fazili et al. (2008). While the lowest response (11.6 and 8.6) was recorded with application of $15 \mathrm{~kg}$ sulphur alone in both years. Similar findings in rice-wheat cropping system were also reported by Singh et al. 2017.

\section{Energy use efficiency}

Energy consumed, net energy return and energy productivity with different rates of nitrogen and sulphur fertilisation is depicted in Table 6. Higher energy was consumed with application higher rates of sulphur and nitrogen. Similar trend was recorded related to output energy. The net energy return was found higher with application of $15 \mathrm{~kg} \mathrm{~N} / \mathrm{ha}$ and $30 \mathrm{~kg}$ $\mathrm{S} / \mathrm{ha}$ compared to other treatments. Ramesh et al.2018 also found variation in energy input and out put energy with different levels of fertilizer application in maize based cropping system. Lowest energy productivity $(\mathrm{kg} / \mathrm{MJ})$ was recorded with no application of nitrogen and sulphur fertilizer, followed by combined application of $15 \mathrm{~kg} \mathrm{~N} / \mathrm{ha}$ and $30 \mathrm{~kg} \mathrm{~S} / \mathrm{ha}$ compared to other treatments. Variation in input energy and output energy with different nitrogen rates in maize-wheat cropping system was also depicted by Khokhar et al. (2017).

\section{Economics}

Combined application of $15 \mathrm{~kg} \mathrm{~N} / \mathrm{ha}$ with $30 \mathrm{~kg} \mathrm{S/ha} \mathrm{recorded}$ higher mean benefit cost ratio (3.94) compared to other treatment combination (Table 7). Higher $\mathrm{B}: \mathrm{C}$ may be attributed higher grain yield than $\mathrm{N}_{0} \mathrm{~S}_{1}, \mathrm{~N}_{0} \mathrm{~S}_{2}, \mathrm{~N}_{0} \mathrm{~S}_{3}, \mathrm{~N}_{1} \mathrm{~S}_{0}$, $\mathrm{N}_{1} \mathrm{~S}_{1}-, \mathrm{N}_{2} \mathrm{~S}_{0} \mathrm{~N}_{2} \mathrm{~S}_{1}$ - (Table 4) and lower cost of cultivation than $\mathrm{N}_{1} \mathrm{~S}_{3}, \mathrm{~N}_{2} \mathrm{~S}_{2}, \mathrm{~N}_{2} \mathrm{~S}_{3}$. Nina et al. (2021) also found that combined use of nitrogen with sulphur reduced the nitrogen surplus in cabbage and was economical viable.

Table 4: Effect of interaction of different levels of sulphur and nitrogen on seed yield ( $q / h a)$ of field pea.

\begin{tabular}{|c|c|c|c|c|c|c|}
\hline \multirow{3}{*}{ Treatments } & \multicolumn{6}{|c|}{ Seed yield $\mathrm{q} / \mathrm{ha}$} \\
\hline & \multicolumn{3}{|c|}{$2016-17$} & \multicolumn{3}{|c|}{$2017-18$} \\
\hline & $\mathrm{N}_{0}$ & $\mathrm{~N}_{1}$ & $\mathrm{~N}_{2}$ & $\mathrm{~N}_{0}$ & $\mathrm{~N}_{1}$ & $\mathrm{~N}_{2}$ \\
\hline$S_{0}$ & 8.29 & 11.04 & 13.27 & 9.15 & 10.75 & 14.51 \\
\hline $\mathrm{S}_{1}$ & 10.03 & 13.54 & 15.32 & 10.44 & 14.18 & 15.96 \\
\hline $\mathrm{S}_{2}$ & 12.96 & 17.98 & 18.47 & 13.37 & 18.46 & 18.59 \\
\hline \multirow[t]{2}{*}{$\mathrm{S}_{3}$} & 14.47 & 18.1 & 19.01 & 14.19 & 18.52 & 18.94 \\
\hline & & C.D & S.Em \pm & & C.D & S.Em $\underline{+}$ \\
\hline Sulphur $\times$ Nitrogen & & 1.343 & 0.4579 & & 1.443 & 0.468 \\
\hline
\end{tabular}

Table 5: Influence of sulphur and nitrogen fertilization on agronomic efficiency of field pea.

\begin{tabular}{|c|c|c|c|c|c|c|}
\hline \multirow{3}{*}{ Treatments } & \multicolumn{6}{|c|}{ Agronomic efficiency (AE) } \\
\hline & \multicolumn{3}{|c|}{$2016-17$} & \multicolumn{3}{|c|}{$2017-18$} \\
\hline & $\mathrm{N}_{0}$ & $\mathrm{~N}_{1}$ & $\mathrm{~N}_{2}$ & $\mathrm{~N}_{0}$ & $\mathrm{~N}_{1}$ & $\mathrm{~N}_{2}$ \\
\hline $\mathrm{S}_{0}$ & & 18.33 & 16.60 & & 12.67 & 17.87 \\
\hline $\mathrm{S}_{1}$ & 11.60 & 17.50 & 15.62 & 8.60 & 16.77 & 15.13 \\
\hline $\mathrm{S}_{2}$ & 15.57 & 21.53 & 16.97 & 14.07 & 20.69 & 15.73 \\
\hline \multirow[t]{2}{*}{$\mathrm{S}_{3}$} & 13.37 & 16.35 & 14.29 & 11.20 & 15.62 & 13.05 \\
\hline & & C.D & S.Em \pm & & C.D & S.Em+ \\
\hline Sulphur $\times$ Nitrogen & & 1.52 & 0.49 & & 1.76 & 0.58 \\
\hline
\end{tabular}


Nutrient Use Efficiency and Productivity of Field Pea (Pisum sativum L.) Influenced by Combined Nitrogen and Sulphur Application

Table 6: Energy productivity, output energy and net input energy influenced by different rates of nitrogen and sulphur on field pea.

\begin{tabular}{|c|c|c|c|c|c|c|c|}
\hline \multirow[t]{2}{*}{ Treatments } & \multirow{2}{*}{$\begin{array}{l}\text { Input } \\
\text { energy } \\
(\mathrm{MJ} / \mathrm{ha})\end{array}$} & \multicolumn{2}{|c|}{$\begin{array}{l}\text { Output energy } \\
\text { (MJ/ha) }\end{array}$} & \multicolumn{2}{|c|}{$\begin{array}{l}\text { Net energy return } \\
(\mathrm{MJ} / \mathrm{ha})\end{array}$} & \multicolumn{2}{|c|}{$\begin{array}{l}\text { Energy productivity } \\
(\mathrm{kg} / \mathrm{MJ})\end{array}$} \\
\hline & & $2016-17$ & $2017-18$ & $2016-17$ & $2017-18$ & Mean & Mean \\
\hline $\mathrm{N}_{0} \mathrm{~S}_{0}$ & 2014.6 & 22318.05 & 24954.88 & 20303.45 & 22940.28 & 21621.86 & 0.080 \\
\hline $\mathrm{N}_{0} \mathrm{~S}_{1}$ & 2839.6 & 25596.73 & 27621.43 & 22757.13 & 24781.83 & 23769.48 & 0.082 \\
\hline $\mathrm{N}_{0} \mathrm{~S}_{2}$ & 3664.6 & 33320.58 & 34654.03 & 29655.98 & 30989.43 & 30322.70 & 0.082 \\
\hline $\mathrm{N}_{0} \mathrm{~S}_{3}$ & 4489.6 & 36883.28 & 37380.18 & 32393.68 & 32890.58 & 32642.13 & 0.083 \\
\hline $\mathrm{N}_{1} \mathrm{~S}_{0}$ & 2923.6 & 28829.30 & 27543.88 & 25905.70 & 24620.28 & 25262.99 & 0.082 \\
\hline $\mathrm{N}_{1} \mathrm{~S}_{1}$ & 3748.6 & 34341.05 & 37118.60 & 30592.45 & 33370.00 & 31981.23 & 0.082 \\
\hline $\mathrm{N}_{1} \mathrm{~S}_{2}$ & 4573.6 & 45923.85 & 47528.08 & 41350.25 & 42954.48 & 42152.36 & 0.081 \\
\hline $\mathrm{N}_{1} \mathrm{~S}_{3}$ & 5398.6 & 45310.25 & 47754.53 & 39911.65 & 42355.93 & 41133.79 & 0.083 \\
\hline $\mathrm{N}_{2} \mathrm{~S}_{0}$ & 3832.6 & 34744.03 & 37119.83 & 30911.43 & 33287.23 & 32099.33 & 0.082 \\
\hline $\mathrm{N}_{2} \mathrm{~S}_{1}$ & 4657.6 & 39070.90 & 40367.20 & 34413.30 & 35709.60 & 35061.45 & 0.083 \\
\hline $\mathrm{N}_{2} \mathrm{~S}_{2}$ & 5482.6 & 46338.03 & 46682.30 & 40855.43 & 41199.70 & 41027.56 & 0.083 \\
\hline $\mathrm{N}_{2} \mathrm{~S}_{3}$ & 6307.6 & 47892.20 & 47098.05 & 41584.60 & 40790.45 & 41187.53 & 0.084 \\
\hline
\end{tabular}

Table 7: Influence of sulphur and nitrogen fertilization on relative economics of field pea.

\begin{tabular}{lccc}
\hline Treatments & \multicolumn{3}{c}{ B:C } \\
\cline { 2 - 4 } & $2016-17$ & $2017-18$ & Mean \\
\hline $\mathrm{N}_{0} \mathrm{~S}_{0}$ & 1.96 & 2.18 & 2.07 \\
$\mathrm{~N}_{0} \mathrm{~S}_{1}$ & 2.23 & 2.38 & 2.30 \\
$\mathrm{~N}_{0} \mathrm{~S}_{2}$ & 2.82 & 2.93 & 2.88 \\
$\mathrm{~N}_{0} \mathrm{~S}_{3}$ & 3.06 & 3.07 & 3.07 \\
$\mathrm{~N}_{1} \mathrm{~S}_{0}$ & 2.54 & 2.44 & 2.49 \\
$\mathrm{~N}_{1} \mathrm{~S}_{1}$ & 2.97 & 3.18 & 3.08 \\
$\mathrm{~N}_{1} \mathrm{~S}_{2}$ & 3.87 & 4.00 & 3.94 \\
$\mathrm{~N}_{1} \mathrm{~S}_{3}$ & 3.76 & 3.93 & 3.84 \\
$\mathrm{~N}_{2} \mathrm{~S}_{0}$ & 3.03 & 3.27 & 3.15 \\
$\mathrm{~N}_{2} \mathrm{~S}_{1}$ & 3.35 & 3.47 & 3.41 \\
$\mathrm{~N}_{2} \mathrm{~S}_{2}$ & 3.90 & 3.93 & 3.92 \\
$\mathrm{~N}_{2} \mathrm{~S}_{3}$ & 3.94 & 3.89 & 3.92 \\
\hline
\end{tabular}

\section{CONCLUSION}

Based on the results a significant interaction was found between sulphur and nitrogen in terms of number of nodules per plant, seed yield and nutrient use efficiency in field pea. The combined application of nitrogen $(15 \mathrm{~kg} / \mathrm{ha})$ and sulphur (30 kg/ha) was economically viable and also have lower energy consumption. The existing recommended starter dose of nitrogen in field pea is $30 \mathrm{~kg} / \mathrm{ha}$ in Kashmir valley. From the findings of present study ( $30 \mathrm{~kg} \mathrm{~S} / \mathrm{ha}$ and $15 \mathrm{~kg} \mathrm{~N} / \mathrm{ha}$ ) the farmer can save $50 \%$ of starter dose of nitrogen in field pea. Further, the reduced application of nitrogenous fertilizer will reduces losses of different forms of nitrogen to surface water, groundwater and to the atmosphere. Hence, to save the environment and to get higher productivity of field pea, it is recommended to apply $30 \mathrm{~kg}$ of sulphur and $15 \mathrm{~kg} \mathrm{~N} / \mathrm{ha}$ in Kashmir Valley.

\section{REFERENCES}

Bhat, T.A., Gupta, M., Ganai, M.A., Ahanger, R.A. and Bhat, H.A. (2013). Yield, soil health and nutrient utilization of field pea (Pisum sativum L.) as affected by phosphorus and biofertilizers under subtropical conditions of Jammu. International Journal of Modern Plant and Animal Science. 1(1): 1-8.

Chandra, D. and Khaldelwal, R.B. (2009). Effect of P and S nutrition on yield and quality of chickpea (Cicer arietinum L.). Journal of Indian Society of Soil Science. 57: 352-356.

Devasenapathy, P., Senthilkumar, G. and Shanmugam (2009). Energy management in crop production. Indian Journal of Agronomy. 54(1): 80-90.

Dobermann, A. (2007). Nutrient use Efficiency - Measurement and Management. In "IFA International Workshop on Fertilizer Best Management Practices", Brussels, Belgium: 1-28.

FAOSTAT. (2019). http//www.fao.org/faostat/en/\#ho.

Fazli, I.S., Jamal, A., Ahmad, S., Masoodi, M., Khan, J.S. and Abdin, M.Z. (2008). Interactive effect of sulphur and nitrogen on nitrogen accumulation and harvest in oilseed crops differing in nitrogen assimilation potential. Journal of Plant Nutrition. 31: 1203-1220.

Gan, Y.T., Liu, P.H., Sterveson, F.C. and Mcdonald, C.L. (2004). Inter-relationships among yield components of Chickpea In semi-arid environments. Canadian Journal of Plant Science. 83(4): 759-767.

Jamal, A., Fazli, I.S., Ahmad, S. and Abdin, M.Z. (2006). Interactive effect of nitrogen and sulphur on yield and quality of groundnut (Arachis hypogea L.). Korean Journal Crop Science. 51(6): 519-522

Jamal, A., Fazli, I.S., Ahmad, S., Abdin, M.Z., Yun, S.J. (2005). Effect of sulphur and nitrogen application on growth characteristics, seed and oil yield of soybean cultivars. Korean Journal of Crop Science. 50(5): 340-345

Khokhar, A.K., Bawa, S.S., Singh, S., Sharma, V., Sharma, S.C. (2018). Tillage and nutrient-management practices for improving productivity and soil physico-chemical properties 
in maize (Zea mays)-wheat (Triticum aestivum) cropping system under rainfed conditions in Kandi region of Punjab. Indian Journal of Agronomy. 63(3): 278-284.

Lal, H., (2004). Effect of nitrogen and phosphorous on seed yield of pea (Pisum sativum L.) and French bean (Phaseolus vulgaris L.). Progressive Horticulture. 36(1): 150-151.

Liu, J. and Diamond, J. (2005). China's environment in a globalizing world. Nature. 435(7046): 1179-1186.

Ma, Q., Yu, T., Shen, S.M., Zhou, H., Jiang, Z.S. and Xu, Y.G. (2010). Effects of fertilization on nutrient budget and nitrogen use efficiency of farmland soil under different precipitations in Northeastern China. Nutrient Cycling in Agroecosystems. 88(3): 315-327.

Munshi, S.K., Juneja, R. and Juneja, R. (2001). Effect of sulphur on nitrogen assimilation, carbohydrates in nodules as well as leaves and lipids in kernels of peanut (Arachis hypogaea L.). Journal of Plant Biology. 28: 189-198.

Nannim, S., Kuberi, J.R. and Kumdet, A. (2018). The Performance of field pea (Pisum sativum L.) as influenced by nitrogen application and plant density in Vom Plateau State. International Journal of Scientific and Engineering Research. 9(6): 484498.

Nawange, D.D., Yadav, A.S. and Singh, R.V. (2011). Effect of phosphorus and sulphur application on growth, yield attributes and yield of chickpea (Cicer arietinum L). Legume Research. (34): 48-50.

Nina, K.M., Ksenija, S.M., Rok, M., Marijan, N., Metka, H. and Jerneja, J. (2021). Nitrogen and sulphur fertilisation for marketable yields of cabbage [Brassica oleracea (L.) var. Capitata], leaf nitrate and glucosinolates and nitrogen losses studied in a field experiment in central slovenia. Plants. 10(1304): 2-16.
Raja, W., Dar, S.A. and Hussain, Z. (2017). Agronomic evaluation of mungbean genotypes under delayed sowing conditions. Agricultural Science Digest. 37(4): 317-319.

Ramesh, Negi, S.C., Rana, S.S. and Kumar, S. (2018). Effects of resource conservation technologies on productivity, nutrient acquisition, employment generation and energetics of maize (Zea mays)-based cropping systems in NorthWestern Himalayan region. Indian Journal of Agronomy. 63(3): 285-292.

Rao, C.S., Singh, K.K. and Masood, A. (2001). Sulphur: A key nutrient for higher pulse production. Fertiliser News. 46(10): 37-38.

Saad, A.A., Das, T.K., Rana D.S., Sharma, A.R., Bhattacharyya, R., Lal, K. (2016). Energy auditing of a maize-wheatgreengram cropping system under conventional and conservation agriculture in irrigated north-western IndoGangetic Plains. Energy. 116: 293-305.

Sinclair, T., Purcell, L. and Sneller, C. (2004). Crop transformation and the challenge to increase yield potential. Trends in Plant Science. 9: 70-75.

Singh, D.K., Singh, G.D., Singh. R., Chaturvedi, S. and Singh, M. (2017). Himalayas farmer participatory evaluation of balanced application of nutrients in rice (Oryza sativa)wheat (Triticum aestivum) system in Kumaon hills. Indian Journal of Agronomy. 62(4): 401-406.

Tandon, H.L.S. and Messick, D.L. (2007). Practical of Sulphur Guide. The Sulphur Institute, Washington, D.C.: 1-2. 